\title{
Meningkatkan Pendidikan Demokrasi pada Pemilih Pemula
}

\author{
M. Taufan Perdana Putra1, Abdul Hakam S ${ }^{2}$, Erwin Widhiandono ${ }^{3}$ \\ ${ }^{1,2,3} \mathrm{Ilmu}$ Hukum Universitas Islam Balitar, Jl. Majapahit No.2- 4, Kota Blitar, Jawa Timur 66137
}

Correspondence: taufanperdana@unisbablitar.ac.id

Received: 30 Juni 2021 - Revised: 01 Agustus 2021 - Accepted: 16 Agustus 2021

\begin{abstract}
Abstrak. Sangat besar kemungkinan dalam kegiatan politik para kandidat yang mengikutipersaingan dalam pilkada akan menyasar para pemilih pemula yang merupakan kelompok pemilih strategis untuk mengaet suara dari pemilih pemula. Tujuan dilakukannya kegiatan pengabdian ini adalah untuk meningkatkan pendidikaan demokrasi pada pemilih pemula agar dapat menghindari politik uang. Metode yang digunakan dalam kegiatan ini tersusun dari beberapa tahapan yang sudah di susun secara sistematis. Hasil dari kegiatan pengabdian ini adalah kegiatan pengabdian kepada masyaarakat ini berjalan lancar dan para peserta merasa bahwasanya kegiatan webinar ini sangat bermanfaat bagi kalangan muda dan utamanya bagi pemilih pemula agar dapat menghindari politik uang serta lebih meningkatkan rasa demokrasi.
\end{abstract}

Kata kunci: Pendidikan demokrasi, politik uang, pemilih pemula.

Citation Format: Putra, M.T.P., Hakam, A.S., \& Widhiandono, E. (2021). Meningkatkan Pendidikan Demokrasi Pada Pemilih Pemula. Prosiding Seminar Nasional Abdimas Ma Chung (SENAM), 164170 . 


\section{PENDAHULUAN}

Peristiwa kehidupan sosial politik bangsa dalam bingkai demokrasi konstitusional Indonesia sejak reformasi bergulir di negeri ini, belum sepenuhnya sesuai dengan idealitas demokrasi konstitusional yang sebenarnya. Demokrasi adalah jalan yang memungkinkan pemilih menjadi berdaya dan berdaulat (Caroline, 2016). Dalam kenyataannya nilai prinsip dan kaidah dari demokrasi belum dapat dilaksanakan oleh segenap komponen bangsa dengan benar dan penuh kesadaran. Masih banyak terjadi penyimpangan yang merusak kehidupan demokratisasi bangsa, bak itu dilakukan secara sengaja maupun tidak. Menurut Sumantri (1998) dalam penelitian Bambang (2018) realitas seperti ini disebut sebagai "undemocratic democracy," yaitu suatu tatanan kehidupan berbangsa dan bernegara yang struktur (institusi) demokrasinya sudah ada, tetapi semangat dan perwujudannya masih jauh dari cita-cita demokrasi. Kondisi yang dirasakan paradoksal antara realitas dengan nilai dan norma yang diajarkan atau dipidatokan.

Rasa demokrasi dapat timbul salah satunya pada saat kegiatan pemilu. Agar tidak mudah terjerumus kedalam hal yang meyesatkan pada saat terjadinya pemilu sehingga mengakibatkan terjadinya tindakan yang tidak demokratis maka pemilih perlu memperoleh pendidikan mengenai pendidikan demokrasi. Pendidikan bagi pemilih merupakan bagian penting dalam kegiatan pemilu maupun. Pendidikan pemilih merupakan bagian dari penyelenggaraan pemilu. Sedangkan pemilih muda merupakan salah satu isu penting yang mendapat perhatian baik bagi penyelenggara pemilu maupun peserta pemilu. Kepentingan peserta pemilu terhadap pemilih muda berkaitan dengan suara, sedangkan bagi penyelenggara agar pemilih muda berpartisipasi dalam pemilu (Rozuli \& Haboddin, 2018).

Pendidikan pemilih sejatinya dilakukan secara terus menerus. Namun, fakta menunjukkan lain. Pendidikan pemilih hanya dilakukan menjelang pemilihan, dan aktor yang melakukan pendidikan pemilih adalah penyelenggara pemilu, partai politik, dan masyarakat sipil yang konsen dengan isu pemilu. Dengan aktor penyelenggara tersebut, maka kegiatan pendidikan pemilih selalu dimaknai dengan pemberian suara dan pemberian hak politik.

Pendidikan pemilih pemula merupakan bagian dari sosialisasi politik yang harus dilakukan untuk meningkatkan partisipasi serta kualitas partisipasi pemilih dalam kehidupan politik. Sosialisasi politik adalah suatu proses penginternalisasian nilai nilai politik, kepercayaan dan sikap politik. Sosialisasi politik sebagai pola dan aspek tindakan 
sosial yang menekankan pada kemampuan, pengetahuan,sikap yang diperlukan individu untuk menjalankan peranya sekarang atau yang akan dating sepanjang kehidupan yang normal sampai peran baru dipelajari. Sementara itu Hyman (1956) dalam Iskandar \& Marlina (2019) mengatakan bahwa sosialisasi politik adalah pembelajaran individu tentang pola sosial yang sesuai dengan posisi sosialnya sebagaimana dimediasi oleh berbagai agen dalam masyarakat.

\section{MASALAH}

Sangat besar kemungkinan dalam kegiatan politik para kandidat yang mengikuti persaingan dalam pilkada akan menyasar para pemilih pemula yang merupakan kelompok pemilih strategis untuk mengaet suara dari pemilih pemula. Maka dengan demikian, pemilih pemula juga harus dibekali dengan nilai-nilai demokrasi agar dapat memutus rantai black campaign, dan menyadari bahwa suara yang mereka miliki akan menentukan nasib mereka lima tahun ke depan. Pada masa sebelum pemilihan kepala daerah dilakukan adalah masa yang penting untuk mendorong pemilih muda agar berpartisipasi saat pemilihan kepala daerah dilakukan.

Potensi politik uang di masa pandemic Covid-19 dapat berupa Pemberian bantuan sosial oleh kandidat atau timnya kepada masyarakat yang keadaan ekonominya terdampak akibat Covid-19. Kemudian pengaturan kampanye melalui daring, membuka peluang adanya pemberian pulsa atau kuota internet dari kandidat atau timnya kepada peserta kampanye.

Berdasarkan kondisi itu lah perlu adanya kegiatan sosialisasi untuk menciptakan pemilih pemula yang cerdas mampu memilah informasi atau kabar bohong dan terhindar dari money politic, bertanggungjawab dan aktif berpartisipasi menciptakan pemerintahan yang mampu menjalankan fungsi dan tugas demi mensejahterakan rakyatnya.

\section{METODE PELAKSANAAN}

Kegiatan pengabdian ini dilakukan di Blitar secara online melalui zoom. Peserta kegiatan pengabdian ini sejumlah 35 peserta. Metode pengembangan dalam kegiatan pengabdian ini dilakukan dengan berbagai rangkaian tahapan yang disusun secara sistematis sebgai berikut:

1. Pembuatan materi

2. Pembuatan konsep sosialisasi

3. Pelaksanaan sosialisasi secara online 


\section{HASIL DAN PEMBAHASAN}

Pemilu pada prinsipnya merupakan mekanisme penyaluran pendapat rakyat secara berkala. Bagi negara demokrasi penyelenggaraan pemilu dapat dipandang sebagai awal dari paradigma demokrasi (Suewoto, 1990). Pemilu pada prinsipnya adalah wujud penyaluran kedaulatan rakyat secara langsung. Karena pemilihan umum diselenggarakan bertujuan:

1) Untuk memungkinkan terjadinya peralihan kepemimpinan pemerintahan secara tertib dan damai

2) Untuk memungkinkan terjadinya penggantian pejabat yang akan mewakili kepentingan rakyat di lembaga perwakilan

3) Untuk melaksanakan prinsip kedaulatan rakyat, dan

4) Untuk melaksanakan prinsip hak-hak asasi warga negara (Asshiddiqie, 2006).

Pelaksanaan kegiatan pengabdian masyarakat berjudul Meningkatkan Pendidikan Demokrasi Pada Pemilih Pemula telah dilaksanakan sesuai dengan metode yang telah ditetapkan. Kegiatan ini dilaksanakan secara online pada hari Sabtu, 7 Agustus 2021. Kegiatan pengabdian kepada masyarakat ini diikuti sebanyak 35 peserta dari kalangan mahasiswa.

Kegiatan pengabdian ini diawali dengan penyampaian materi mengenai Pendidikan Demokrasi Bagi Pemilih Pemula yang disampaikan oleh Dosen Ilmu Hukum yaitu Bapak Erwin Widhiandono, SH., MH. Pada sesi ini dijelaskan bahwa terdapat perbedaan dari pemilih muda dan pemilih pemula. Pemilih pemula dan pemilih muda dikategorisasikan berdasarkan usia. Pemilih pemula (first time voter) adalah orang yang baru pertama kali menggunakan hak pilihnya dalam pemilu, usianya antara 17-21 tahun. Pemilih muda (young voter) adalah pemilih yang berusia 17 sampai 30 tahun (batasan usia pemuda berdasarkan UU Nomor 40 Tahun 2009).

Kemudian dilanjut pemaparan materi oleh Dosen Ilmu Hukum yaitu Abdul Hakam Sholahuddin, S.Ag., MH mengenai Pendidikan Antipolitik Uang Bagi Pemilih Pemula. Dalam materi tersebut dijelaskan yang menjadi sasaran utama dari politikuang yaitu pemilih pemula, ibu-ibu, dan kelompok masyarakat marjinal. Banyak dampak yang ditimbulkan dari adanya politik uang yaitu pemimpin menjadi tidak kompeten, terjadi penyalahgunaan APBD, para pemimpin yang terpilih dari hasil money politic akan mencari jalan untuk bisa balik modal dengan cara mutasi jabatan dan proyek. 


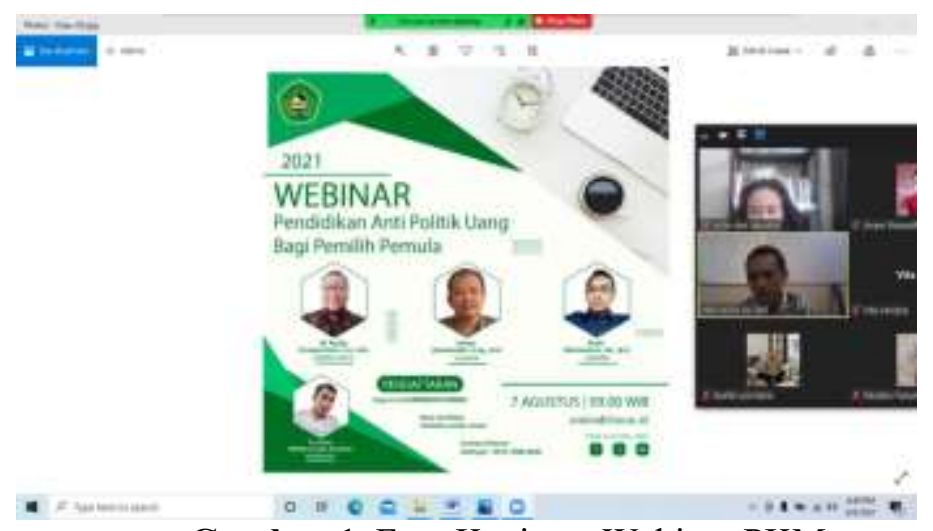

Gambar 1. Foto Kegiatan Webinar PKM

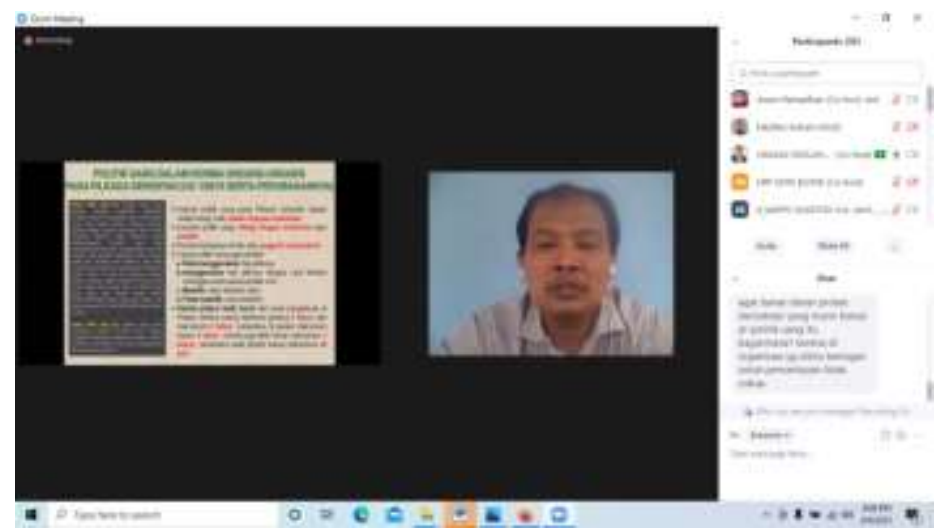

Gambar 2. Pemaparan Materi Oleh Bapak Hakam

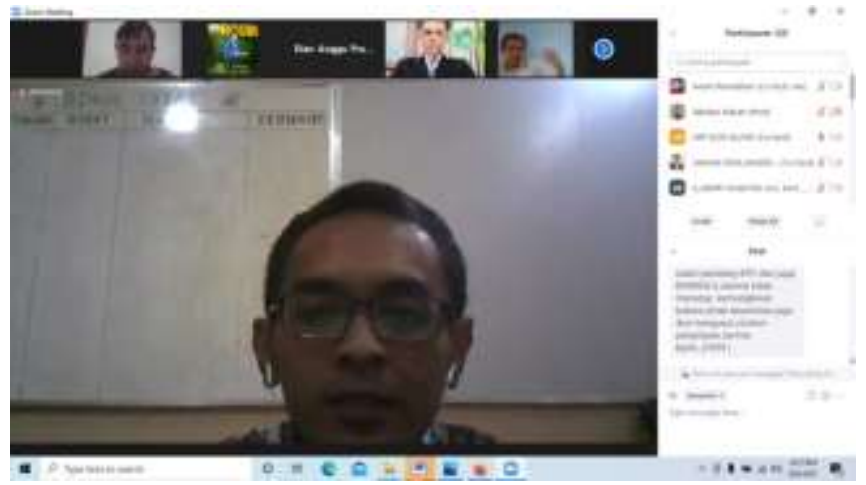

Gambar 3. Pemaparan Materi Oleh Bapak Erwin

Setelah selesainya kegiatan webinar peserta diarahkan untuk menjawab beberapa pertanyaan yang ada di google form terkait evaluasi kegiatan pengabdian ini. Dari jawaban peserta tersebut diketahui bahwa mayoritas peserta yang mengikuti kegiatan webinar ini sudah pernah bahkan ada yang sering mendapat tawaran politik uang. Namun ada juga 
yang belum pernah mengalami hal tersebut. Mereka yang pernah mengalami hal tersebut merasa tidak setuju dengan adanya politik uang karena dapat merusak demokrasi.

Kemudian respon peserta setelah mengikuti kegiatan webinar ini adalah para peserta sangat paham terkait materi yang disampaikan oleh anggota tim pengabdian. Kemudian peserta juga merasa puas mengikuti kegiatan webinar yang dilaksanakan oleh anggota pengabdian. Mereka menyatakan bahwa webinar ini sangat bermanfaat bagi kalangan muda dan utamanya bagi pemilih pemula agar dapat menghindari politik uang serta lebih meningkatkan rasa demokrasi.

\section{KESIMPULAN}

Setelah selesainya rangkaian kegiatan webinar pengabdian kepada masyarakat dengan judul Meningkatkan Pendidikan Demokrasi Pada Pemilih Pemula dapat ditarik kesimpulan bahwa kegiatan pengabdian kepada masyaarakat ini berjalan lancar dan para peserta merasa bahwasanya kegiatan webinar ini sangat bermanfaat bagi kalangan muda dan utamanya bagi pemilih pemula agar dapat menghindari politik uang serta lebih meningkatkan rasa demokrasi.

\section{UCAPAN TERIMA KASIH}

Terimakasih kami sampaikan kepada Universitas Islam Balitar yang telah mendanai kegiatan ini. Tak lupa kami sampaikan terimakasih kepada keseluruhan anggota yang turut ikut membantu kegiatan pengabdian ini.

\section{DAFTAR PUSTAKA}

Asshiddiqie, J. (2005). Konstitusi dan Konstitusionalisme Indonesia, Jakarta.

Bambang Yuniarto, B. Y. (2018). Pendidikan Demokrasi dan Budaya Demokrasi Konstitusional (Vol. 1). Deepublish.

Iskandar, D., \& Marlina, N. (2019). Pendidikan Pemilih Muda Cerdas di Kabupaten Boyolali. Jurnal Pengabdian Vokasi, 1(1), 12-18.

Mulyosudarmo, S. (1990). Kekuasaan dan Tanggung Jawab Presiden Republik Indonesia. Suatu Penelitian Segi-Segi Teoritik dan Yuridis Pertanggungjawaban Kekuasaan, Universitas Airlangga, Surabaya.

Paskarina, C. (2016). Pilkada Serentak, Eksklusi Partai Politik, dan Masa Depan Politik Representasi. The POLITICS: Jurnal Magister Ilmu Politik Universitas Hasanuddin, 24-38.

Rozuli, A. I., \& Haboddin, M. (2018). Pendidikan Pemilih dan Penguatan Demokrasi. Politea: Jurnal Politik Islam, 1(2), 129-148. 
(c) (1)

(c) 2021 by authors. Content on this article is licensed under a Creative Commons Attribution 4.0 International license. (http://creativecommons.org/licenses/by/4.0/). 